Rev. Int. Contam. Ambie. 34 (4) 621-634, 2018

DOI: 10.20937/RICA.2018.34.04.06

\title{
EFFECT OF pH, MINING TAILINGS CONCENTRATION AND CULTURE MEDIUM ON THE PERFORMANCE OF POLYMETALLIC BIOLEACHING AT FLASK LEVEL
}

\author{
David Enrique ZAZUETA-ÁLVAREZ, Hiram MEDRANO-ROLDÁN, Damián REYES-JÁQUEZ, \\ María Dolores Josefina RODRÍGUEZ-ROSALES and Cuauhtémoc Ulises MORENO-MEDINA*
}

Instituto Tecnológico de Durango, Blvd. Felipe Pescador 1830, Nueva Vizcaya, 34080 Durango, Durango, México

*Author for correspondence: cumorenome@conacyt.mx

(Received May 2017; accepted February 2018)

Key words: biological acidification, biological oxidation, medium without nitrogen source

\begin{abstract}
The aim of this research was to evaluate bioleaching of $\mathrm{Mn}, \mathrm{As}, \mathrm{Pb}$ and $\mathrm{Zn}$ from mining tailings using two different sets of variable processing conditions. In the first $\operatorname{set} \mathrm{pH}(2.0$, 4.0 and 6.0), tailings concentrations $(10,20$ y $30 \%$, w/v [111.11, 250.00 and 428.57 $\mathrm{g} / \mathrm{L}$, respectively]), and two types of culture medium (9K [with nitrogen source] and nonN (nitrogen-free medium) were evaluated; in the second set the evaluation focused on continuous supplementation of biogenic $\mathrm{H}_{2} \mathrm{SO}_{4}$ oxidized with two types of culture medium ( $9 \mathrm{~K}$ and nonN) at different tailings concentrations (10, 20 y $30 \%, \mathrm{w} / \mathrm{v}$ [111.11, 250.00 and $428.57 \mathrm{~g} / \mathrm{L}$, respectively]), with continuous supplementation of the media previously described ( $9 \mathrm{~K}$ and nonN) oxidized by the native strains Leptospirillum ferriphilum and Leptospirillum ferrooxidans. In the first set, the highest removal of Mn (93.49\%), As (13.92\%) and $\mathrm{Pb}(>99 \%)$ was observed in both media at $10 \%$ of tailings and initial $\mathrm{pH}$ of 2.0. In the second experimental set, the highest removal of $\mathrm{Mn}$ $(99 \%)$, As (> $85 \%), \mathrm{Pb}(>99 \%)$ and $\mathrm{Zn}(67 \%)$ was found with both media at $10 \%$ of tailings and initial $\mathrm{pH}$ 6.0. Continuous supplementation of biologically acidified and oxidized culture media enhanced the metals removal from solid waste or tailings. Similar metals removal in media without nitrogen compared to medium with nitrogen was observed in this research.
\end{abstract}

Palabras clave: acidificación biológica, oxidación biológica, medio sin fuente de nitrógeno

\section{RESUMEN}

El presente trabajo evaluó la biolixiviación de $\mathrm{Mn}, \mathrm{As}, \mathrm{Pb}$ y $\mathrm{Zn}$ de desechos mineros a pH y concentración de sólidos cercanos al usado en la cianuración. Se realizaron dos experimentos. El primero evaluó pH (2.0, 4.0 y 6.0), concentración de jales (10, 20 y $30 \%, \mathrm{p} / \mathrm{v}[111.11,250.00$ y $428.57 \mathrm{~g} / \mathrm{L}$, respectivamente]) y dos tipos de medios de cultivo (9K [con fuente de nitrógeno] y nonN [sin fuente de nitrógeno]). El segundo evaluó la suplementación continua de iones férricos bioxidados en dos tipos de medios de cultivo (9K y nonN) a diferentes concentraciones de jales $(10,20$ y $30 \%$, p/v [111.11, 250.00 y $428.57 \mathrm{~g} / \mathrm{L}$, respectivamente]) con la suplementación continua de los medios de cultivo anteriormente descritos ( $9 \mathrm{~K}$ y nonN) pero bioxidados con las cepas nativas Leptospirillum ferriphilum y Leptospirillum ferrooxidans. En el primer experimento, las mayores eliminaciones de $\mathrm{Mn}(93.49 \%)$, As (13.92 \%) y $\mathrm{Pb}(>99 \%)$ se observaron con ambos medios de cultivo, al $10 \%$ de jales y pH inicial 2.0. En el 
segundo experimento, las mayores remociones de $\mathrm{Mn}$ (99\%), As (> $85 \%), \mathrm{Pb}(99 \%)$ y $\mathrm{Zn}(67 \%)$ se observaron en ambos medios de cultivo, al $10 \%$ de jales y $\mathrm{pH}$ inicial 6.0. La suplementación continua de medio acidificado y oxidado biológicamente aceleró e incrementó la eliminación de metales del residuo minero sólido o jal. Se observó eliminación de metales en el medio sin nitrógeno.

\section{INTRODUCTION}

Finding more efficient methods to extract metals from polymetallic sources, such as electronic and mine wastes, has become a very important topic, since current deposits are far from matching the increasing demand (Watling 2015).

Some metals, such as manganese oxides, act as refractory agents, which unfortunately are common components in silver ores mainly found in the southeastern USA, Latin America and China (Clevenger and Caron 1925).

In the presence of manganese oxides in ores, silver resists attacks by cyanide, since manganese minerals occlude silver by forming a structural bound. This is due to the fact that silver grains are very finely disseminated as isomorphism in the crystal lattices of manganese minerals.

Manganese itself may cause excessive consumption of cyanide as a consequence of complexes formation (Qiu et al. 2014). Pyrolusite $\left(\mathrm{MnO}_{2}\right)$ is the most abundant manganese compound found in silver ores.

Usually, manganese is surrounding the dispersed silver compounds, making them inaccessible to the leaching solution. In addition, silver-manganese ores possess some silver compounds that are leachingresistant, resulting in an increase of this ore's refractoriness. Silver mineral is primarily found with higher oxides, which makes difficult its isolation and subsequent identification (Gandhi and Sarkar 2016). Furthermore, the recalcitrant nature of $\mathrm{MnO}_{2}$ limits conventional mineral recovery methods.

Other metals like $\mathrm{As}, \mathrm{Co}, \mathrm{Pb}$ and $\mathrm{Zn}$ are getting increasingly scarce, owing to a decreasing tendency of ore grades, insufficient environmental-friendly technologies and the increasing demand from developing countries (UNEP 2009, Graedel and Cao 2010). Some authors expect a depletion of $\mathrm{Mn}, \mathrm{Pb}$, $\mathrm{Zn}$, As and Ag in approximately 50 years (Backman 2008, Dodson et al. 2012).

An option to minimize this problem is to take advantage of alternative sources of metals such as waste ores and tailings, which are usually abandoned at mine sites. Bioleaching technology is an environmental-friendly technology used to extract metals from complex mineralogical sources, such as tailings.

Bioleaching has several advantages: (i) short construction times, (ii) low cost, (iii) there is no need for a specialist, since bioleaching systems are easy to operate and maintain, $(i v)$ it is possible to use native bacteria that are adapted to the specific complexity of polymetallic materials, and $(v)$ it is possible to regenerate leaching media with the aid of microorganisms, which therefore minimize wastes (Akinci and Guven 2011, Johnson 2014, Watling 2015, Fonti et al. 2016).

Some authors observed simultaneous bioleaching of several metals from polymetallic matrixes (Ijadi Bajestani et al. 2014, Nguyen et al. 2015a, b). In order to take advantage of bioleaching in mine tailings, an important issue to consider is the relative high $\mathrm{pH}$ (9-11) of such matrices.

As wastes of a cyanide silver recovery process, the tailings were amended to a $\mathrm{pH}$ around 9-11, which is necessary for an efficient silver extraction $(\mathrm{Li}$ et al. 1992, Li and Wadsworth 1993, Sun et al. 1996, Jiang et al. 2015, Olyaei et al. 2016). Setting the $\mathrm{pH}$ to optimal values for bioleaching bacteria $(\mathrm{pH} \leq 2)$ increases economic costs and restricts this technology to tailings with sufficient metals concentrations to make this option profitable (Mireles 2015).

Reports of polymetallic bioleaching are scarce, especially regarding polymetallic matrices at similar conditions to those commonly observed in the mining industry, i.e., high tailing concentrations ( $>10 \%)$ and high $\mathrm{pH}(>2)$ (Akcil and Gahan 2015). Some authors reported that using native microorganisms is more efficient than many effective consortia constructed in the laboratories (Mousavi et al. 2007, Lavalle et al. 2008, Ghosh and Das 2017, Marchevsky et al. 2017). In addition, the exploitation of such microorganisms would eliminate the need to use standard laboratory cultures, particularly for large-scale studies (Keeling et al. 2005).

The aim of this research was to evaluate at flask level the effects of bioleaching processes using native strains with the following sets of variables: $(a) \mathrm{pH}$ $(2.0,4.0$ and 6.0$)$, tailings concentrations $(10,20$ and $30 \%, w / v)$, and two types of culture medium ( $9 \mathrm{~K}$ and nonN); and (b) continuous supplementation of 
biogenic $\mathrm{H}_{2} \mathrm{SO}_{4}$ synthetized with two culture mediums $(9 \mathrm{~K}$ and nonN) at different tailings concentrations $(10,20$ and $30 \%, \mathrm{w} / \mathrm{v})$.

\section{MATERIALS AND METHODS}

\section{Tailings characterization}

Tailings were kindly donated by First Majestic Silver Corp and obtained from La Encantada mine, located northeast of Torreón, Coahuila, Mexico. Mineral samples for bioleaching testing were obtained after the cyanidation process. The samples were taken from the tailings dump of La Encantada mine, then homogenized and stored in polyethylene containers at ambient temperature.

Tailings were characterized by X-ray diffraction (XRD, Rigaku Miniflex 600 Benchtop) as follows: $100 \mathrm{~g}$ of sample were taken and dried at $50{ }^{\circ} \mathrm{C}$ for $24 \mathrm{~h}$. After that, the sample was pulverized in an agate mill for $3 \mathrm{~min}$ and sieved to obtain a particle size of $50 \mu \mathrm{m}$. Then they were placed in a circular holder to be analyzed from theta 3.0 to 2 -theta 90 , $0.7 \mathrm{deg} / \mathrm{min}$ with steps of $0.02 \mathrm{deg}$. The X-ray $(\mathrm{Cu}$ $\mathrm{K}$-alpha) was operated at tube voltage and current of 40 and $15 \mathrm{~mA}$.

For the analysis in the inductively coupled plasma optical emission spectrometry (ICP-OES, Perkin Elmer 5300DV), $100 \mathrm{~g}$ of sample were dried at $50{ }^{\circ} \mathrm{C}$ for $24 \mathrm{~h}$. After that, the sample was pulverized in an agate mill for $3 \mathrm{~min}$, then $2 \mathrm{~mL}$ of $\mathrm{HNO}_{3}$ were added and the sample was heated at $70^{\circ} \mathrm{C}$ for $30 \mathrm{~min}$. Then $6 \mathrm{~mL}$ of $\mathrm{HCl}$ were added and heated again at $70^{\circ} \mathrm{C}$ for $2 \mathrm{~h}$. Afterwards, $17 \mathrm{~mL}$ were taken and centrifuged at $3000 \mathrm{rpm}$. Finally, the supernatant was analyzed in the ICP-OES. The target metals were $\mathrm{Mn}, \mathrm{As}, \mathrm{Pb}$ and $\mathrm{Zn}$.

\section{Bacterial strain genetic characterization and culture conditions}

Native strains were isolated from La Encantada mine. Bacteria isolation was performed from the wet tailings directly taken from the tailings dump. From this sample, $10 \mathrm{~g}$ were taken and incubated with 90 $\mathrm{mL}$ of $9 \mathrm{~K}$ liquid medium at $160 \mathrm{rpm}$ and $31^{\circ} \mathrm{C}$ by 30 days. The microorganisms suspended in the $9 \mathrm{k}$ liquid medium were used as inocula for subsequent cultures with 9K fresh liquid medium (Liu et al. 2007).

Bacterial native strains were spread in $9 \mathrm{~K}$ liquid medium, with the following initial concentrations: $3.0 \mathrm{~g} / \mathrm{L}\left(\mathrm{NH}_{4}\right)_{2} \mathrm{SO}_{4} ; 0.5 \mathrm{~g} / \mathrm{L} \mathrm{MgSO}_{4} \cdot 7 \mathrm{H}_{2} \mathrm{O} ; 0.1 \mathrm{~g} / \mathrm{L}$ $\mathrm{KCl} ; 0.5 \mathrm{~g} / \mathrm{L} \mathrm{K}_{2} \mathrm{HPO}_{4} ; 0.01 \mathrm{~g} / \mathrm{L} \mathrm{Ca}\left(\mathrm{NO}_{3}\right)_{2}$, and $44.22 \mathrm{~g} / \mathrm{L} \mathrm{FeSO}_{4} \cdot 7 \mathrm{H}_{2} \mathrm{O}$.
Acclimation to the tailings was not performed; we assumed that the strains were already acclimatized to them. The $\mathrm{pH}$ was adjusted to 2.0 with $\mathrm{H}_{2} \mathrm{SO}_{4} 2 \mathrm{~N}$ and incubated at $30{ }^{\circ} \mathrm{C}$ and $160 \mathrm{rpm}$, in $500 \mathrm{~mL}$ baffled Erlenmeyer flasks.

Nitrogen-free medium (nonN) was used as an alternative to cultivate the isolate native strains. The nonN medium contained $44.22 \mathrm{~g} / \mathrm{L} \mathrm{FeSO}_{4} \cdot 7 \mathrm{H}_{2} \mathrm{O}$ and $0.5 \mathrm{~g} / \mathrm{L} \mathrm{K}_{2} \mathrm{HPO}_{4}$; $\mathrm{pH}$ was adjusted to 2.0 with $\mathrm{H}_{2} \mathrm{SO}_{4} 2 \mathrm{~N}$.

Bacterial DNA was extracted following the procedure proposed by Tian et al. (2012).

One milliliter was taken from an overnight culture $\left(1 \times 10^{8} \mathrm{cel} / \mathrm{mL}\right)$ and centrifuged at $13000 \mathrm{rpm}$ for 2 min. Cell pellet was resuspended in $300 \mathrm{~mL}$ of lysis buffer (EDTA, $0.05 \mathrm{M} ; \mathrm{NaCl}, 0.1 \mathrm{M} ; \mathrm{pH} 7.5$ ) by gentle vortexing for $30 \mathrm{~s}$; afterwards, $100 \mathrm{~mL}$ of lysozyme solution $(10 \mathrm{mg} / \mathrm{mL})$ and $30 \mu \mathrm{L}$ of SDS solution, $20 \%$ $(\mathrm{w} / \mathrm{v})$, were added.

The mix was incubated at $37^{\circ} \mathrm{C}$ for $5 \mathrm{~min}$. DNA was purified using a mix of phenol-chloroform-isoamyl alcohol (25:24:1, vol/vol/vol). Extracted DNA was used as a template to amplify a conserved $16 \mathrm{~S}$ ribosomal DNA (rDNA) region for total bacteria by polymerase chain reaction (PCR), using primer pair, forward 5'-CCGTCAATTCCTTTGAGTTT-3' and reverse 5'-GTGCCAGCAGCCGCGGTAA-3'.

Approximately $20 \mathrm{ng}$ of purified DNA were used per reaction combined with $2.5 \mu \mathrm{L}$ of $10 \mathrm{X}$ PCR buffer, $1 \mu \mathrm{L}$ of $\mathrm{MgCl}_{2}$ (25 mmol), $1 \mu \mathrm{L}$ of dNTP mixture (20 mmol), $1 \mu \mathrm{L}$ for each primer $(10 \mathrm{mmol}), 0.25 \mu \mathrm{L}$ $(5 \mathrm{U} / \mu \mathrm{L})$ of GoTaq DNA polymerase (Promega); all dissolved in $18.25 \mu \mathrm{L}$ of sterile milliQ water.

PCR was programed as follows: initial DNA denaturation at $95{ }^{\circ} \mathrm{C}$ for $5 \mathrm{~min}$, followed by 10 cycles of nesting (denaturation $30 \mathrm{~s}$ at $94{ }^{\circ} \mathrm{C}$, annealing from $65-55^{\circ} \mathrm{C}$ for $30 \mathrm{~s}$, lowering temperature by $0.5^{\circ} \mathrm{C}$ for each cycle and a final extension of $30 \mathrm{~s}$ at $72{ }^{\circ} \mathrm{C}$ ). In addition, 30 cycles of $30 \mathrm{~s}$ at $94{ }^{\circ} \mathrm{C}, 30 \mathrm{~s}$ at $55^{\circ} \mathrm{C}, 30 \mathrm{~s}$ at $72{ }^{\circ} \mathrm{C}$ and a final extension at $72^{\circ} \mathrm{C}$ for 10 min were performed $\left(\mathrm{T} 100^{\mathrm{TM}}\right.$ Thermal Cycler, BIO-RAD).

The PCR product was sequenced and compared using the basic local alignment search tool through its official website (http://www.ncbi.nlm.nih.gov) (Altschul et al. 1990). The PCR products were sent for sequencing to the University Unit of Massive Sequencing and Bioinformatics of the National Autonomous University of Mexico.

A Genome Analyzer IIx (Illuminia) was used for sequencing. The Illumina protocol (Illumina 2007) used for the sample preparation is briefly described as follows: 
a) Add 'A' bases to the 3' end of the DNA fragments (adds an "A" base to the 3' end of the blunt phosphorylated DNA fragments, using the polymerase activity of Klenow fragment (3' to 5' exo minus). This prepares the DNA fragments for ligation to the adapters, which have a single ' $\mathrm{T}$ ' base overhang at their 3' end).

b) Ligate adapters to DNA fragments (ligates adapters to the ends of the DNA fragments, preparing them to be hybridized to a flow cell).

c) Purify ligation products (purifies the products of the ligation reaction on a gel to remove all un-ligated adapters, remove any adapters that may have ligated to one another, and select a size-range of templates to go on the cluster generation platform).

d) Enrich the adapter-modified DNA fragments by PCR (uses PCR to selectively enrich those DNA fragments that have adapter molecules on both ends, and to amplify the amount of DNA in the library. Only 14 cycles of PCR are employed, to avoid skewing the representation of the library.)

\section{Experimental design}

All experiments were carried out for 17 days to improve the target metals solubilization, in accordance with some authors (Gericke et al. 2008, Lavalle et al. 2008, Nguyen et al. 2015b).

For the first set of experiments, the effects on metals removal of the following parameters were evaluated: initial $\mathrm{pH}(2.0,4.0$ and 6.0), tailings concentration $(10,20$ and $30 \%, \mathrm{w} / \mathrm{v}$ [111.11, 250.00 and $428.57 \mathrm{~g} / \mathrm{L}$, respectively]) and $\left(\mathrm{NH}_{4}\right)_{2} \mathrm{SO}_{4}$ addition ( $9 \mathrm{~K}$ and nonN medium).

Experiments were performed in $500 \mathrm{~mL}$ baffled Erlenmeyer flasks. In the flasks, $100 \mathrm{~mL}$ of the respective medium was inoculated with $10 \% \mathrm{v} / \mathrm{v}$ of native bacterial culture supernatant and incubated at $30^{\circ} \mathrm{C}$ and $160 \mathrm{rpm}$. Initial $\mathrm{pH}$ and tailings concentration were adjusted following the experimental design previously described.

The purpose of the second set of experiments was to evaluate the effect of: ( $i$ ) biogenic $\mathrm{H}_{2} \mathrm{SO}_{4}$ medium continuous supplementation, (ii) tailings concentration, and (iii) $\left(\mathrm{NH}_{4}\right)_{2} \mathrm{SO}_{4}$ in pre-biogenic $\mathrm{H}_{2} \mathrm{SO}_{4}$ mediums on metals removal. This set of experiments was performed as follows:

First, pre-biogenic $\mathrm{H}_{2} \mathrm{SO}_{4}$ mediums were obtained from cultures grown in $9 \mathrm{~K}$ and nonN mediums. The cultures were performed in $500 \mathrm{~mL}$ baffled Erlenmeyer flasks: $100 \mathrm{~mL}$ of the respective medium were added and inoculated with $10 \% \mathrm{v} / \mathrm{v}$ of native bacterial culture supernatant at $\mathrm{pH}$ of 2.0 , which was adjusted with $\mathrm{H}_{2} \mathrm{SO}_{4} 2 \mathrm{~N}$.
Cultures were incubated in a rotatory shaker at $160 \mathrm{rpm}$ and $30^{\circ} \mathrm{C}$ for $2-5$ days until $\mathrm{Fe}^{2+}$ was completely oxidized. After the precipitate was removed, the solutions were analyzed to determine the concentrations of $\mathrm{Fe}^{3+}$.

Next, 111.11, 250.00 and $428.57 \mathrm{~g} / \mathrm{L}(10,20$ and $30 \%, \mathrm{w} / \mathrm{v}$ ) of tailings were added to $500 \mathrm{~mL}$ baffled Erlenmeyer flasks and volume was adjusted to 100 $\mathrm{mL}$ using their respective oxidized media (9K or nonN).

Experiments were carried out by triplicate for 17 days. Initial $\mathrm{pH}$ of 6.0 was adjusted with $\mathrm{H}_{2} \mathrm{SO}_{4} 2 \mathrm{~N}$ in all experiments.

Continuous supplementation of the fresh biological oxidized medium was added to the respective tailings concentration every $24 \mathrm{~h}$ for 17 days (Fig. 1). The medium was separated by centrifugation at 1500 rpm for $15 \mathrm{~min}$. Later, the fresh biological oxidized medium was added to the respective tailings concentration and incubated at $160 \mathrm{rpm}$ and $30^{\circ} \mathrm{C}$.

\section{Monitoring and control techniques}

Changes in $\mathrm{pH}$ and oxidation-reduction potential (ORP) were monitored regularly at intervals of $24 \mathrm{~h}$ for 17 days, using a Hanna pH/ORP Meter HI 2114P.

The concentration of $\mathrm{Fe}^{2+}$ was determined by titration of potassium dichromate with N-phenylanthranilic acid as an indicator (Welcher 1963). The concentration of $\mathrm{Fe}^{3+}$ was determined by titration of EDTA at pH 2.0 with sulfosalicylic acid as an indicator (Davis and Jacobsen 1960). Responses were Mn, $\mathrm{As}, \mathrm{Pb}$ and $\mathrm{Zn}$ removal, quantified by ICP-OES as described in the tailings characterization section. All determinations were performed by triplicate.

\section{Statistical analysis}

Full factorial design was used to evaluate: $(i)$ the effects of initial $\mathrm{pH}(2.0,4.0$, and 6.0), tailings concentration (10, 20 and $30 \%, \mathrm{v} / \mathrm{w})$ and two types of culture medium ( $9 \mathrm{~K}$ and nonN) for the first set of experiments, and (ii) tailings concentration (10, 20 and $30 \%, \mathrm{v} / \mathrm{w}$ ) with continuous supplementation of two biogenic acids mediums ( $9 \mathrm{~K}$ and nonN) for the second set of experiments. The response was the removal of $\mathrm{Mn}, \mathrm{As}, \mathrm{Pb}$ and $\mathrm{Zn}$. The design was developed and analyzed using commercial software Minitab $17^{\circledR}$ (Minitab, State College, PA, USA).

\section{RESULTS AND DISCUSSION}

The XRD characterization of tailings (Fig. 2) indicated that calcite is the mayor component 


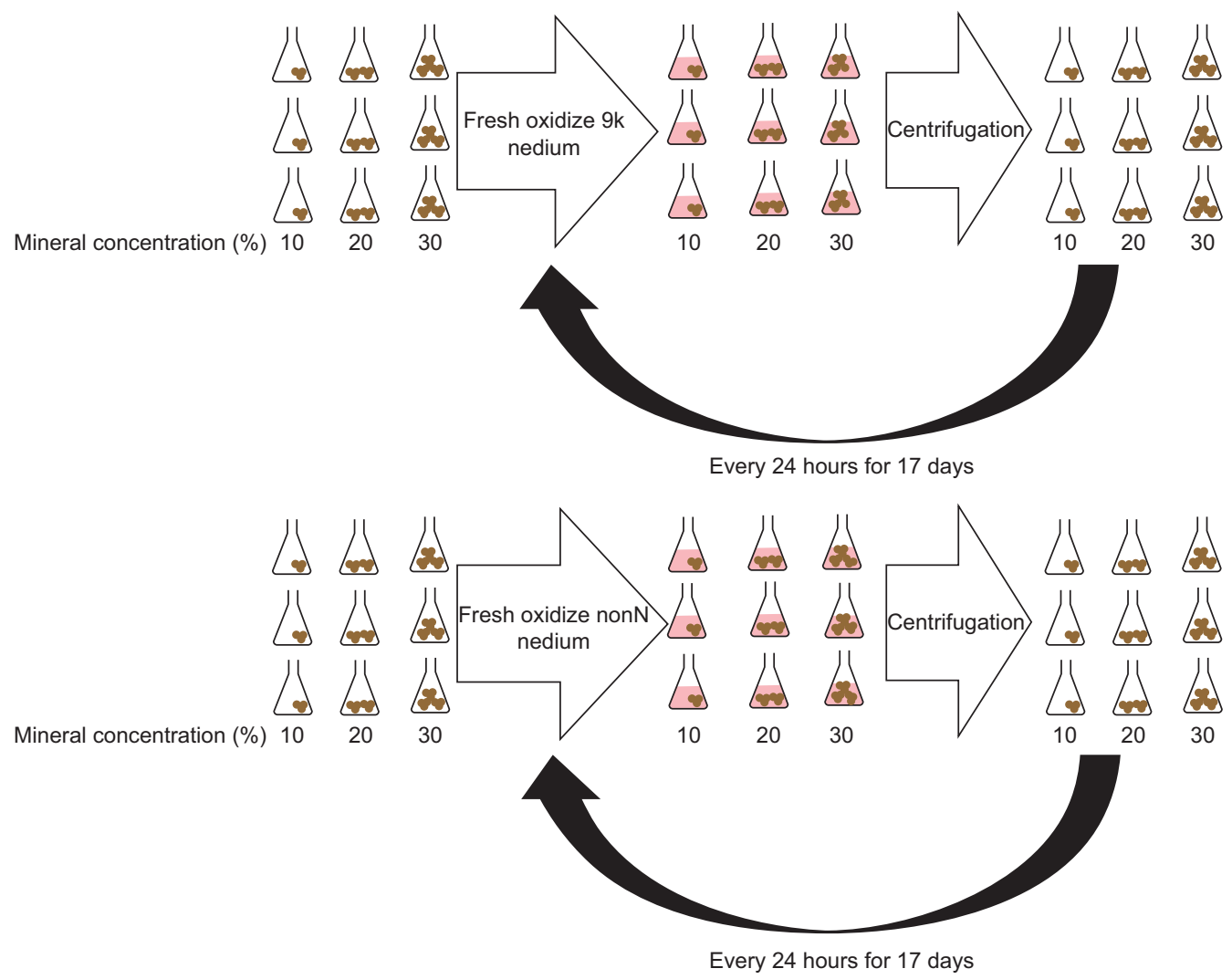

Fig. 1. Experimental procedure of the second experimental set

(56.2\%), followed by the minor components (2-10\%) $\mathrm{Fe}, \mathrm{Si}, \mathrm{Mn}$ and $\mathrm{Zn}$ in the forms of hematite, goethite, quartz, nepheline, kaolinite and loseyite, and finally by the trace components $(<2 \%)$, represented in general by compounds with $\mathrm{Pb}, \mathrm{Mn}, \mathrm{Zn}$ and $\mathrm{As}$, such as rhodochrosite, plumbojarosite, pyrolusite, hemimorphite and mimetite among others. Tailings composition and abundances are shown in table $\mathbf{I}$.

Certain components in tailings can affect the performance of native bioleaching strain, specifically

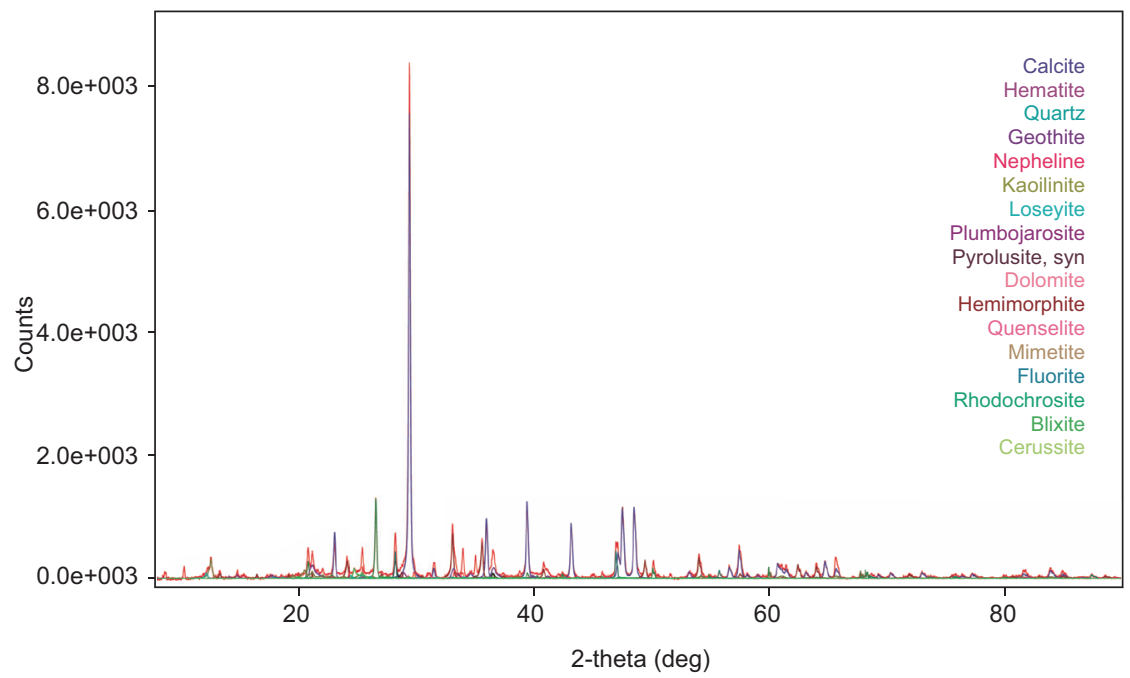

Fig. 2. X-ray diffraction of the tailings 
TABLE I. TAILINGS COMPOSITION

\begin{tabular}{|c|c|c|c|}
\hline Element & Abundance (\%) & Compound formula & Abundance $(\%)$ \\
\hline $\mathrm{Mn}$ & 2.93 & Calcite: $\mathrm{CaCO}_{3}$ & 56.2 \\
\hline $\mathrm{Pb}$ & 2.35 & Hematite: $\mathrm{Fe}_{2} \mathrm{O}_{3}$ & 7.6 \\
\hline $\mathrm{Zn}$ & 1.96 & Goethite: $\mathrm{FeO}(\mathrm{OH})$ & 7.5 \\
\hline As & 0.30 & Quartz: $\mathrm{SiO}_{2}$ & 6.1 \\
\hline \multirow[t]{13}{*}{$\mathrm{Ag}$} & $142 \mathrm{~g} / \mathrm{t}$ & Nepheline: $(\mathrm{Na}, \mathrm{K}) \mathrm{AlSiO}_{4}$ & 3.8 \\
\hline & & Kaolinite: $\mathrm{Al}_{2} \mathrm{Si}_{2} \mathrm{O}_{5}(\mathrm{OH})_{4}$ & 2.9 \\
\hline & & Loseyite: $(\mathrm{Mn}, \mathrm{Zn})_{7}(\mathrm{OH})_{10}\left(\mathrm{CO}_{3}\right)_{2}$ & 2.7 \\
\hline & & Rhodochrosite: $\mathrm{MnCO}_{3}$ & 1.9 \\
\hline & & Plumbojarosite: $\mathrm{Pb}\left(\mathrm{Fe}_{3}(\mathrm{OH})_{6}\left(\mathrm{SO}_{4}\right)_{2}\right)_{2}$ & 1.7 \\
\hline & & Pyrolusite: $\mathrm{MnO}_{2}$ & 1.7 \\
\hline & & Dolomite, $\mathrm{CaMg}\left(\mathrm{CO}_{3}\right)_{2}$ & 1.6 \\
\hline & & Hemimorphite: $\mathrm{Zn}_{4}\left(\mathrm{Si}_{2} \mathrm{O}_{7}\right)(\mathrm{OH})_{2} \cdot \mathrm{H}_{2} \mathrm{O}$ & 1.5 \\
\hline & & Quenselite: $\mathrm{PbMnO}_{2}(\mathrm{OH})$ & 1.4 \\
\hline & & Mimetite: $\mathrm{Pb}_{5}\left(\mathrm{AsO}_{4}\right)_{3} \mathrm{Cl}$ & 1.1 \\
\hline & & Fluorite: $\mathrm{CaF}_{2}$ & 1 \\
\hline & & Blixite: $\mathrm{Pb}_{2} \mathrm{Cl}(\mathrm{O}, \mathrm{OH})_{2}-\mathrm{x}$ & 0.9 \\
\hline & & Cerussite: $\mathrm{PbCO}_{3}$ & 0.4 \\
\hline
\end{tabular}

Note: All data are averages from replicates and standard deviation was lower than $5 \%$

$\mathrm{CaCO}_{3}$ (Fig. 2), since it neutralizes $\mathrm{H}_{2} \mathrm{SO}_{4}$ produced by the bacteria, thus decreasing acid leaching (Lombardi and García 2002).

Calcite is present in tailings as a waste from silver extraction by cyanidation, and, as mentioned above, tailings were previously exposed to this process. For an efficient cyanidation it is very important to set $\mathrm{pH}$ to alkaline conditions ( $\mathrm{Li}$ et al. 1992, $\mathrm{Li}$ and Wadsworth 1993, Sun et al. 1996).

Additionally, bioleaching microorganisms able to oxidize either inorganic sulfur compounds and/or iron (II) are extremely acidophilic $(\mathrm{pH}<3.0)$ (Rohwerder et al. 2003). Nevertheless, bioleaching activity was observed in all the experimental units (Table II).

Bioleaching bacteria produce the adherence of extracellular polymeric substances (EPS) to minerals and provide a site between the metal sulfide surface and the cells in which iron (III)-ions are accumulated (Bellenberg et al. 2014). This site creates microenvironments with conditions for bioleaching processes (Yu et al. 2008, 2011).

Isolated native strains showed 99 and $97 \%$ of DNA similarity with Leptospirillum ferriphilum and Leptospirillum ferrooxidans, respectively. Isolated native strains also showed proliferation, $\mathrm{Fe}^{2+}$ oxidation and medium acidification in nonN medium, similar to the strain in reported by Corbett (2011).

However, no authors reported the presence of genes involved in $\mathrm{N}_{2}$ fixation in L. ferriphilum (Levicán et al. 2008, Corbett 2011), suggesting that this microorganism can use alternative mechanisms to assimilate nitrogen such as the ATP supplied by Fe-S clusters for fixing nitrogen (Tyson et al. 2004, Ram et al. 2005). The genes responsible of the Fe-S cluster assembly for nitrogen fixation are nifS-nifU$h e s B$ - $h s c B$ - $h s c A$-fdx-orfl (Parro and Moreno-Paz 2003).

Additionally, L. ferrooxidans is able to fix atmospheric nitrogen and can act as a nitrogen fixer for both isolated strains. For $\mathrm{N}_{2}, L$. ferrooxidans can use the nifHDKENX operon to encode the structural component of molybdenum-iron nitrogenase, make modifications to their chemotaxis, and use a coppertransporting ATPase (Parro and Moreno-Paz 2003, Tyson et al. 2005, Sato et al. 2009).

The mediums $9 \mathrm{~K}$ and nonN showed similar behavior in ORP and $\mathrm{pH}$-time ratio at the same tailings concentrations (Figs. 3, 4). The highest removals of metals $(93.49,13.92$ and $>99 \%$ for $\mathrm{Mn}$, As and $\mathrm{Pb}$, respectively) were found at initial $\mathrm{pH} 2.0$ and tailings concentrations of $10 \%$. The final $\mathrm{pH}$ was $<4.0$ and ORP $>300 \mathrm{mV}$.

Several authors have reported the highest metals removal at low solids concentration and $\mathrm{pH}$ (Peng et al. 2008, Gericke and Pinches 1999, Zhang et al. 2010, Tian et al. 2012, Yan-Fei et al. 2013, Yang et al. 2015).

Ahmadi et al. (2015) reported bioleaching of copper $(55 \%)$, nickel $(98.2 \%)$ and cobalt $(59.5 \%)$ after 30 days at $5 \%(\mathrm{w} / \mathrm{v})$ of tailings density. Tailings were a low-grade sulfide ore from the Golgohar iron mine, Iran. Experiments were carried out at flask level with 
TABLE II. METALS REMOVALS EFFICIENCIES OBSERVED IN ALL EXPERIMENTAL UNITS

\begin{tabular}{|c|c|c|c|c|c|c|c|c|}
\hline \multirow{3}{*}{$\begin{array}{c}\text { Tailings } \\
\text { concentration } \\
(\%, \mathrm{w} / \mathrm{v})\end{array}$} & \multicolumn{6}{|c|}{$\begin{array}{c}\text { Batch } \\
\text { Initial pH }\end{array}$} & \multirow{2}{*}{\multicolumn{2}{|c|}{$\begin{array}{c}\text { Semicontinous } \\
\text { Initial } \mathrm{pH} \\
6\end{array}$}} \\
\hline & \multicolumn{2}{|c|}{2} & \multicolumn{2}{|c|}{4} & \multicolumn{2}{|c|}{6} & & \\
\hline & $9 \mathrm{~K}$ & nonN & $9 \mathrm{~K}$ & nonN & $9 \mathrm{~K}$ & nonN & $9 \mathrm{~K}$ & nonN \\
\hline & \multicolumn{8}{|c|}{ Manganese removal (\%) } \\
\hline 10 & $93.49^{\mathrm{ab}}$ & $90.21^{\mathrm{bc}}$ & $37.17^{\mathrm{e}}$ & $35.95^{\mathrm{e}}$ & $37.01^{\mathrm{e}}$ & $36.02^{\mathrm{e}}$ & $>99^{\mathrm{a}}$ & $>99^{\mathrm{a}}$ \\
\hline 20 & $83.49^{\mathrm{cd}}$ & $80.37^{\mathrm{d}}$ & $36.80^{\mathrm{e}}$ & $36.18^{\mathrm{e}}$ & $33.24^{\mathrm{e}}$ & $32.12^{\mathrm{e}}$ & $96.23^{\mathrm{a}}$ & $>99^{\mathrm{a}}$ \\
\hline \multirow[t]{2}{*}{30} & $20.94^{\mathrm{f}}$ & $18.04^{\mathrm{f}}$ & $17.31^{\mathrm{f}}$ & $16.05^{\mathrm{f}}$ & $15.86^{\mathrm{f}}$ & $14.11^{\mathrm{f}}$ & $90.98^{\mathrm{ab}}$ & $95.52^{\mathrm{ab}}$ \\
\hline & \multicolumn{8}{|c|}{ Arsenic removal (\%) } \\
\hline 10 & $13.92^{\mathrm{f}}$ & $12.11^{\mathrm{fg}}$ & $9.60^{\mathrm{gh}}$ & $8.88^{\mathrm{gh}}$ & $9.04^{\mathrm{gh}}$ & $8.54^{\mathrm{gh}}$ & $>99^{\mathrm{a}}$ & $85.33^{b}$ \\
\hline 20 & $7.63^{\mathrm{h}}$ & $7.32^{\mathrm{h}}$ & $7.12^{\mathrm{h}}$ & $7.18^{\mathrm{h}}$ & $7.86^{\mathrm{gh}}$ & $6.85^{\mathrm{h}}$ & $53.12^{\mathrm{c}}$ & $48.00^{\mathrm{d}}$ \\
\hline \multirow[t]{2}{*}{30} & $6.03^{\mathrm{h}}$ & $5.01^{\mathrm{h}}$ & $5.96^{\mathrm{h}}$ & $5.10^{\mathrm{h}}$ & $6.08^{\mathrm{h}}$ & $5.44^{\mathrm{h}}$ & $53.10^{\mathrm{c}}$ & $42.66^{\mathrm{e}}$ \\
\hline & \multicolumn{8}{|c|}{ Lead removal (\%) } \\
\hline 10 & $>99^{\mathrm{a}}$ & $95.54^{\mathrm{abc}}$ & $>99^{\mathrm{a}}$ & $96.32^{\mathrm{ab}}$ & $>99^{\mathrm{a}}$ & $98.21^{\mathrm{a}}$ & $>99^{\mathrm{a}}$ & $>99^{\mathrm{a}}$ \\
\hline 20 & $95.74^{\mathrm{abc}}$ & $94.28^{\mathrm{abcd}}$ & $>99^{\mathrm{a}}$ & $94.25^{\text {abcd }}$ & $88.51^{\text {bcde }}$ & $85.56^{\mathrm{def}}$ & $>99^{\mathrm{a}}$ & $95.23^{\mathrm{ab}}$ \\
\hline \multirow[t]{2}{*}{30} & $80.43^{\text {ef }}$ & $78.58^{\mathrm{f}}$ & $80.85^{\mathrm{ef}}$ & $78.29^{\mathrm{f}}$ & $86.6^{\text {cdef }}$ & $84.22^{\text {cdef }}$ & $>99^{\mathrm{a}}$ & $85.13^{\text {cdef }}$ \\
\hline & \multicolumn{8}{|c|}{ Zinc removal (\%) } \\
\hline 10 & $66.45^{\mathrm{de}}$ & $61.45^{\mathrm{efg}}$ & $69.44^{\mathrm{bcd}}$ & $65.23^{\mathrm{def}}$ & $77.99^{\mathrm{a}}$ & $74.14^{\mathrm{ab}}$ & $68.39^{\mathrm{bcd}}$ & $67.43^{\mathrm{cd}}$ \\
\hline 20 & $20.78^{j}$ & $19.52^{\mathrm{j}}$ & $58.97^{\mathrm{fg}}$ & $55.28^{\mathrm{gh}}$ & $77.78^{\mathrm{a}}$ & $74.52^{\mathrm{abc}}$ & $67.42^{\mathrm{cd}}$ & $49.83^{\text {hi }}$ \\
\hline 30 & $20.59^{j}$ & $17.21^{\mathrm{j}}$ & $57.91^{\mathrm{g}}$ & $55.44^{\mathrm{gh}}$ & $61.54^{\mathrm{efg}}$ & $60.98^{\mathrm{efg}}$ & $60.58^{\mathrm{f}}$ & $45.92^{\mathrm{i}}$ \\
\hline
\end{tabular}

Note: All data are averages from replicates, standard deviation was lower than $5 \%$. Different letters indicate significant differences $(\mathrm{p}<0.05)$

a stirring rate of $150 \mathrm{rpm}$ at $45^{\circ} \mathrm{C}$ and inoculated with a mixture of moderately thermophilic culture. The medium contained a nitrogen source and yeast extract $(0.02 \%[\mathrm{w} / \mathrm{w}])$. Under our conditions, bioleaching was probably driven by biogenic $\mathrm{H}_{2} \mathrm{SO}_{4}$, evidenced by low $\mathrm{pH}$ values (Figs. 3, 4).

Askari-Zamani et al. (2005) evaluated rhenium bioleaching from molybdenite concentrate. Maximum rhenium extraction ( $7.3 \%$ ) was obtained with a native strain of Acidithiobacillus ferrooxidans isolated from the same mine where the concentrate was extracted. The experiment was performed at flask level with $10 \%$ of molybdenite concentrate, $200 \mathrm{~mL}$ of iron-free $9 \mathrm{~K}$ medium and $9 \mathrm{~g}$ of energy source for bacteria growth (ferrous sulfate, pyrite or elemental sulfur powder). Flasks were incubated in an orbital shaker at $120 \mathrm{rpm}$ and $35^{\circ} \mathrm{C}$.

On the other hand, the lowest removals of metals were found at high initial $\mathrm{pH}(4.0$ and 6.0) and high concentrations of tailings (20 and $30 \%$ ): 14-36, 5-7, and $92-78 \%$ for $\mathrm{Mn}$, As and $\mathrm{Pb}$, respectively (final $\mathrm{pH}$ was $>7.0$ and $\mathrm{ORP}<300 \mathrm{mV}$ ).

High tailings concentrations decreased Mn, As and $\mathrm{Pb}$ removal, probably by the lower availability of oxygen and $\mathrm{CO}_{2}$ dissolved in the aqueous phase, resulting in a restricted $\mathrm{H}_{2} \mathrm{SO}_{4}$ of both biogenic production and bacterial $\mathrm{Fe}^{2+}$ ion oxidation.

Therefore, bacterial activity ( $\mathrm{pH}$ and redox) at high pulp concentrations needs more time to achieve similar performances as the ones obtained using low pulp concentrations. Low bacterial growth reduces $\mathrm{H}_{2} \mathrm{SO}_{4}$ production, and, consequently, it reduces the $\mathrm{Mn}, \mathrm{As}$ and $\mathrm{Pb}$ solubilization rate, as observed in this research.

Also, this tendency is probably enhanced by the presence of $\mathrm{CaCO}_{3}$ in tailings. High $\mathrm{CaCO}_{3}$ concentration was observed in tailings (56.2\%), acting as an alkalinizing agent and consuming $\mathrm{H}_{2} \mathrm{SO}_{4}$ biosinthetized by L. ferriphilum and L. ferrooxidans.

In reference to the potential (Eh)-pH diagram (Takeno 2005), highest $\mathrm{Mn}, \mathrm{As}$ and $\mathrm{Pb}$ removals were obtained when $\mathrm{Fe}^{2+}$ iron was the predominant component (final $\mathrm{pH}<3.0$ and ORP 200-500 mV).

The lowest $\mathrm{Mn}, \mathrm{As}$ and $\mathrm{Pb}$ removals were observed when $\mathrm{Fe}_{2} \mathrm{O}_{3}$ was the predominant component (final pH 7.0-8.0 and ORP around $200 \mathrm{mV}$ ). The highest $\mathrm{Zn}$ removal was observed at initial $\mathrm{pH}$ of 6.0. ORP and $\mathrm{pH}$ were $200 \mathrm{mV}$ and 8.0 in average, respectively. According to Takeno (2005), Zn can be present as $\mathrm{Zn}^{2+}$ or $\mathrm{ZnOH}$. 


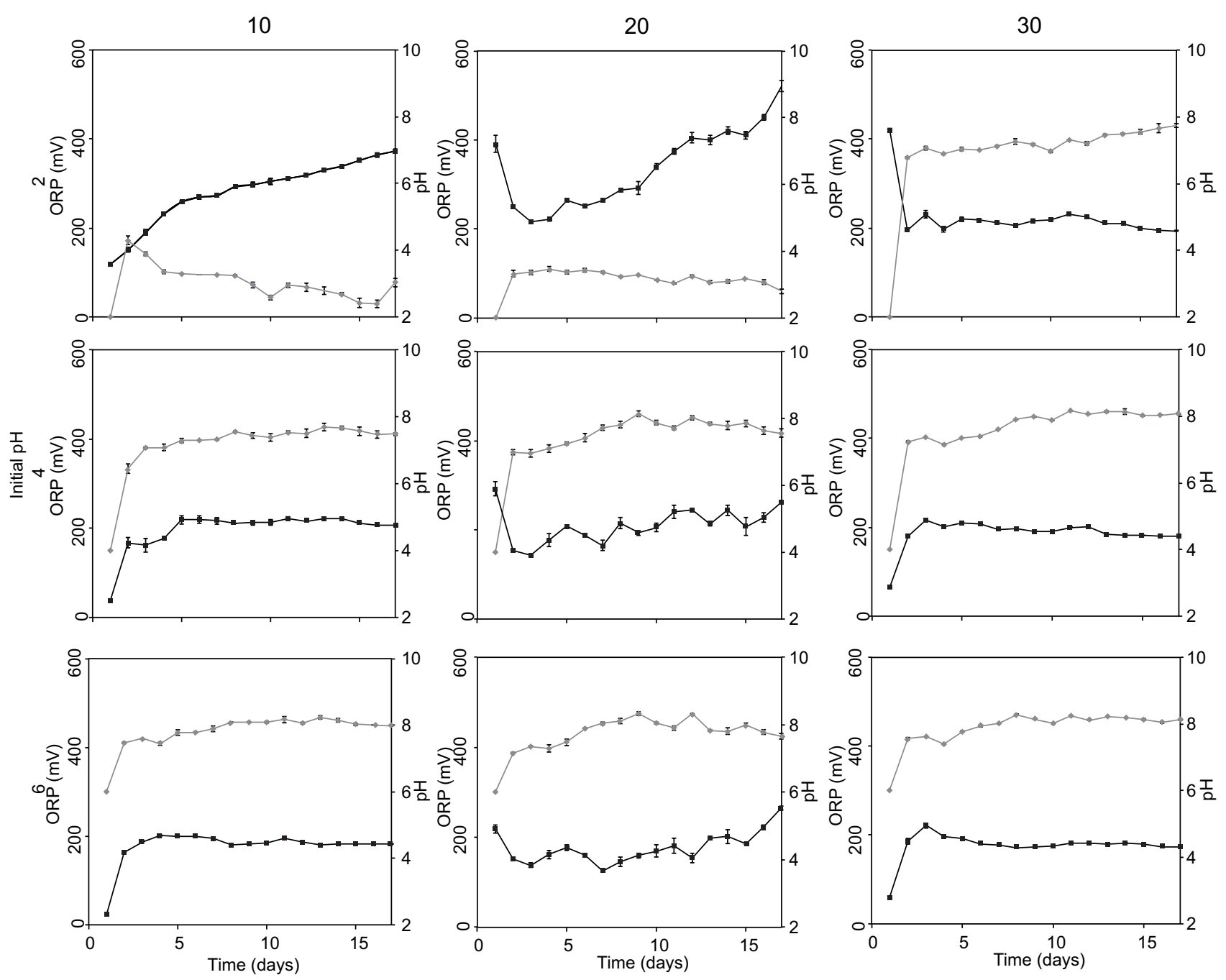

Fig. 3. Oxidation-reduction potential (ORP) and $\mathrm{pH}$ time course at three tailing concentrations, three initial $\mathrm{pH}$ and medium with nitrogen source $(9 \mathrm{~K})$. Oxidation-reduction potential: $\mathbf{m} ; \mathrm{pH}:$

$\mathrm{H}_{2} \mathrm{SO}_{4}$ by itself is incapable to solubilize $\mathrm{MnO}_{2}$. the presence of a reducing agent (such as $\mathrm{H}_{2} \mathrm{O}_{2}$ or $\mathrm{Fe}^{2+}$ ion) is necessary to catalyze the Mn solution (Jiang et al. 2004, Bafghi et al. 2008, Tian et al. 2012), as shown in reactions 1 and 2 .

$$
\begin{aligned}
& \mathrm{MnO}_{2}+\mathrm{H}_{2} \mathrm{O}_{2}+\mathrm{H}_{2} \mathrm{SO}_{4} \rightarrow \mathrm{MnSO}_{4}+2 \mathrm{H}_{2} \mathrm{O}+\mathrm{O}_{2} \\
& 2 \mathrm{Fe}^{2+}+\mathrm{MnO}_{2}+4 \mathrm{H}^{+} \rightarrow \mathrm{Mn}^{2+}+2 \mathrm{Fe}^{3+}+2 \mathrm{H}_{2} \mathrm{O}
\end{aligned}
$$

Ferrous ion is added to the medium as an electron source for $L$. ferriphilum. $\mathrm{H}_{2} \mathrm{O}_{2}$ formation is mediated by the reaction of ferrous and ferric iron with dissolved oxygen in water. As Cohn et al. (2006) reported: $(i)$ $\mathrm{H}_{2} \mathrm{O}_{2}$ synthesis with superoxide $(\mathrm{O} 2 \bullet)^{-}$acts as an intermediate species mediated by dissolved $\mathrm{O}_{2}$ and $\mathrm{Fe}(\mathrm{II})$ via the Haber-Weiss reaction mechanism, and (ii) $\mathrm{Fe}$ (III) extracts an electron from a water molecule, resulting into a hydroxyl radical and then combining two hydroxyl radicals into an $\mathrm{H}_{2} \mathrm{O}_{2}$ formation.

Initial $\mathrm{pH}$, tailings concentration and type of medium showed a significant effect on $\mathrm{Mn}$, As and $\mathrm{Zn}$ removal $(\mathrm{p}<0.05)$.

Carbonated mineral species observed in tailings, such as rhodochrosite $\left(\mathrm{MnCO}_{3}\right)$ and loseyite $\left[(\mathrm{Mn}, \mathrm{Zn})_{7}(\mathrm{OH})_{10}\left(\mathrm{CO}_{3}\right)_{2}\right]$, can be dissolved by direct protonation catalyzed by biogenic $\mathrm{H}_{2} \mathrm{SO}_{4}$ (Luo and Millero 2003). 

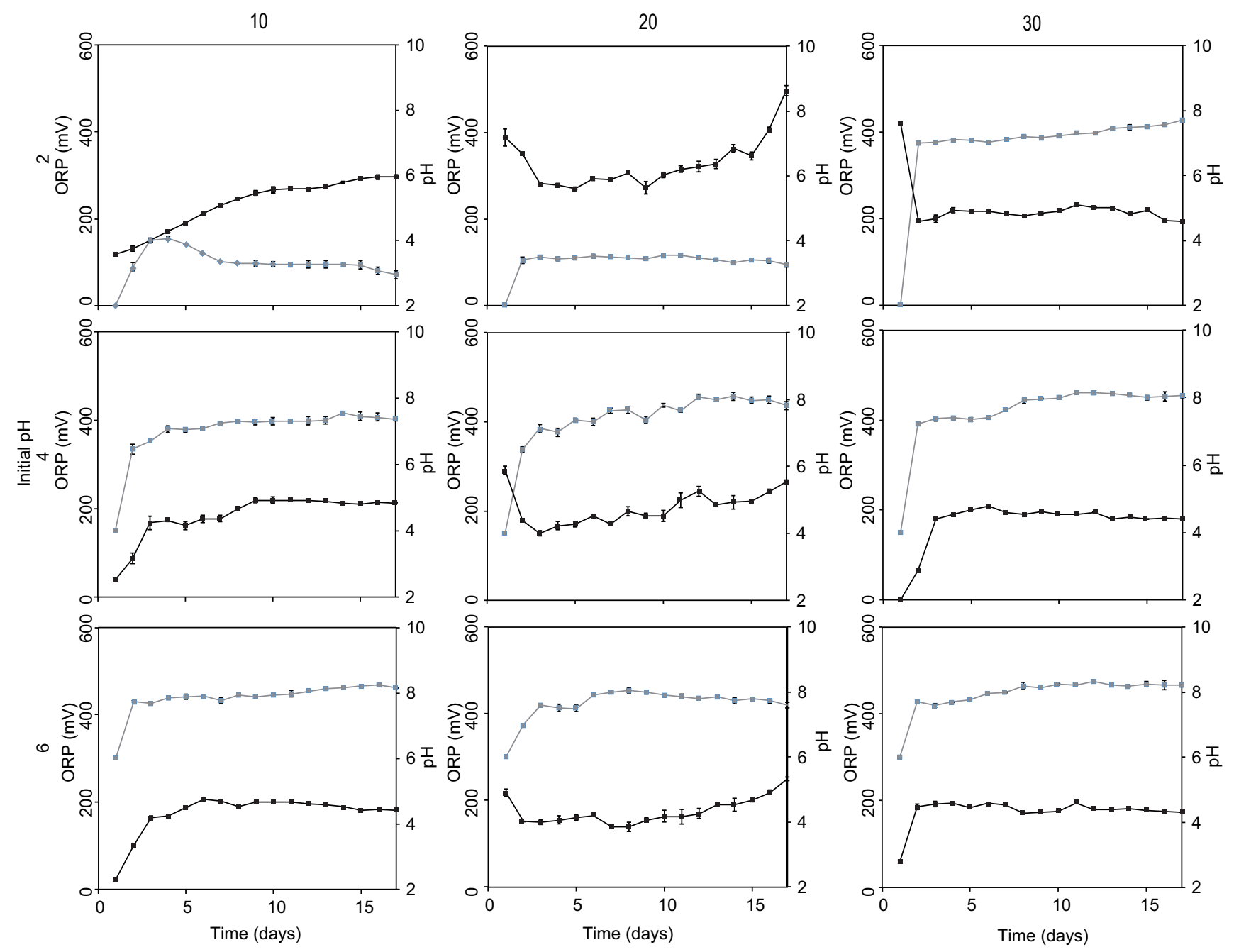

Fig. 4. Oxidation-reduction potential (ORP) and $\mathrm{pH}$ time course at three tailing concentrations, three initial $\mathrm{pH}$ and medium without nitrogen source $($ nonN). Oxidation-reduction potential: $\mathbf{a} ; \mathrm{pH}$ :

Steger (1976) reported the complete dissolution of rhodochrosite in $8 \%$ of $\mathrm{H}_{2} \mathrm{SO}_{4}(\mathrm{pH} \approx 0.85)$, whilst Macías et al. (2012) observed high dissolution of $\mathrm{Zn}$ and $\mathrm{Mn}$ (77 and $86 \%$, respectively) in loseyite by using an oxidizing medium $\left(8.8 \mathrm{~mol} / \mathrm{L} \mathrm{H}_{2} \mathrm{O}_{2}\right.$ and $\mathrm{pH}$ 2.0), compared to $\mathrm{Zn}$ and $\mathrm{Mn}$ dissolution (12 and $10 \%$, respectively) by aqua regia digestion $(12 \mathrm{~mol} / \mathrm{L} \mathrm{HCl}$ and $15.8 \mathrm{~mol} / \mathrm{HNO}_{3}$ in a 3:1 ratio).

For all the media evaluated in this report with high $\mathrm{pH}$ and tailings concentrations, probably the removal of metals obtained was mainly influenced by chemical lixiviation catalyzed by $\mathrm{Fe}^{2+}$ and biogenic $\mathrm{H}_{2} \mathrm{SO}_{4}$ (reaction 2) (Nguyen et al. 2015b).

However, Lombardi and García Jr. (2002) found the highest Mn removal ( $80 \%$ ) in medium at $300 \mathrm{mV}$ of redox potential and $\mathrm{pH}$ of 3.0 inoculated with $A$. ferrooxidans (formerly Thiobacillus ferrooxidans). L. ferriphilum and L. ferrooxidans probably improve the metals leaching by EPS.

Pseudomonas putida strain MnB1 EPS can enhance the dissolution of rhodochrosite in mediums with $\mathrm{pH}$ ranging from 5.0 to 8.0. This effect can be attributed to $\mathrm{N}-\mathrm{H}, \mathrm{C}=\mathrm{O}$ and $\mathrm{C}-\mathrm{H}$ groups found in EPS (Wang and Pan 2014).

Tailings concentration and type of medium presented a significant effect on $\mathrm{Pb}$ removal $(\mathrm{p}<0.05)$. Mimetite $\left(\mathrm{Pb}_{5}\left(\mathrm{AsO}_{4}\right)_{3} \mathrm{Cl}\right)$ and hemimorphite $\left(\mathrm{Zn}_{4}\left(\mathrm{Si}_{2} \mathrm{O}_{7}\right)\right.$ $\left.(\mathrm{OH})_{2} \cdot \mathrm{H}_{2} \mathrm{O}\right)$ can be dissolved by protonation.

Turek et al. (2015) observed in mimetite five and 11 times more $\mathrm{As}$ and $\mathrm{Pb}$ dissolved at $\mathrm{pH}$ of 2.5 compared to 3.75, respectively. McPhail et al. (2003) reported hemimorphite solubilization at $\mathrm{pH} 3.0-6.0$ and $50{ }^{\circ} \mathrm{C}$. 
TABEL III. PEARSON'S CORRELATION MATRIX OF BATCH REGIME EXPERIMENTAL UNITS (P-VALUE IS REPORTED IN PARENTHESIS)

\begin{tabular}{|c|c|c|c|c|c|c|}
\hline Variable & Initial $\mathrm{pH}$ & $\begin{array}{c}\text { Tailing } \\
\text { concentration }\end{array}$ & $\begin{array}{c}\text { Mn } \\
\text { removal }\end{array}$ & $\begin{array}{c}\text { As } \\
\text { removal }\end{array}$ & $\begin{array}{c}\mathrm{Pb} \\
\text { removal }\end{array}$ & $\begin{array}{c}\mathrm{Zn} \\
\text { removal }\end{array}$ \\
\hline Initial $\mathrm{pH}$ & 1 & $0.000(1.000)$ & $-0.568(0.000)$ & $-0.243(0.077)$ & $-0.013(0.927)$ & $0.735(0.000)$ \\
\hline Tailing concentration & & 1 & $-0.593(0.000)$ & $-0.842(0.000)$ & $-0.849(0.000)$ & $-0.467(0.000)$ \\
\hline Mn removal & & & 1 & $0.759(0.000)$ & $0.609(0.000)$ & $-0.148(0.286)$ \\
\hline As removal & & & & 1 & $0.725(0.000)$ & $0.379(0.005)$ \\
\hline $\mathrm{Pb}$ removal & & & & & 1 & $0.338(0.012)$ \\
\hline Zn removal & & & & & & 1 \\
\hline
\end{tabular}

Plumbojarosite $\left(\mathrm{Pb}\left(\mathrm{Fe}_{3}(\mathrm{OH})_{6}\left(\mathrm{SO}_{4}\right)_{2}\right)_{2}\right)$ is a recalcitrant mineral. Patiño et al. (2014) observed its solubilization at $\mathrm{pH} 11.20$, and Viñals and Núñez (1988) at $\mathrm{pH} 0.75$, demonstrating that only extreme $\mathrm{pH}$ values can solubilize this compound. High redox and $\mathrm{pH}<3$ probably drive the leaching in the experiments with low $\mathrm{pH}$ and tailings concentration.

Results obtained from the first set of experiments showed three significant positive correlations (Table III):

- Mn-As removal correlation presumably reveals simultaneous dissolution of mimetite and loseyite, since these minerals are dissolved at $\mathrm{pH} 3.0-2.0$; $\mathrm{Zn}$ removal-initial $\mathrm{pH}$ correlation is associated to high $\mathrm{Zn}$ removal found at initial $\mathrm{pH}$ 6.0; and $\mathrm{As}-\mathrm{Pb}$ removal correlation probably indicates dissolution of mimetite.

- $\mathrm{Pb}$ and As removal had the highest negative correlation with tailings concentration, which could be explained by the abatement of biogenic leaching agent $\left(\mathrm{H}_{2} \mathrm{SO}_{4}\right)$.

- Bioleaching in continuous supplementation of biogenic $\mathrm{H}_{2} \mathrm{SO}_{4}$, synthetized in two culture media at different concentrations of tailings are shown on table II and figure 5.

Continuous supplementation of acid medium can catalyze metals solubilization at high tailings concentrations, since results similar to the highest values in
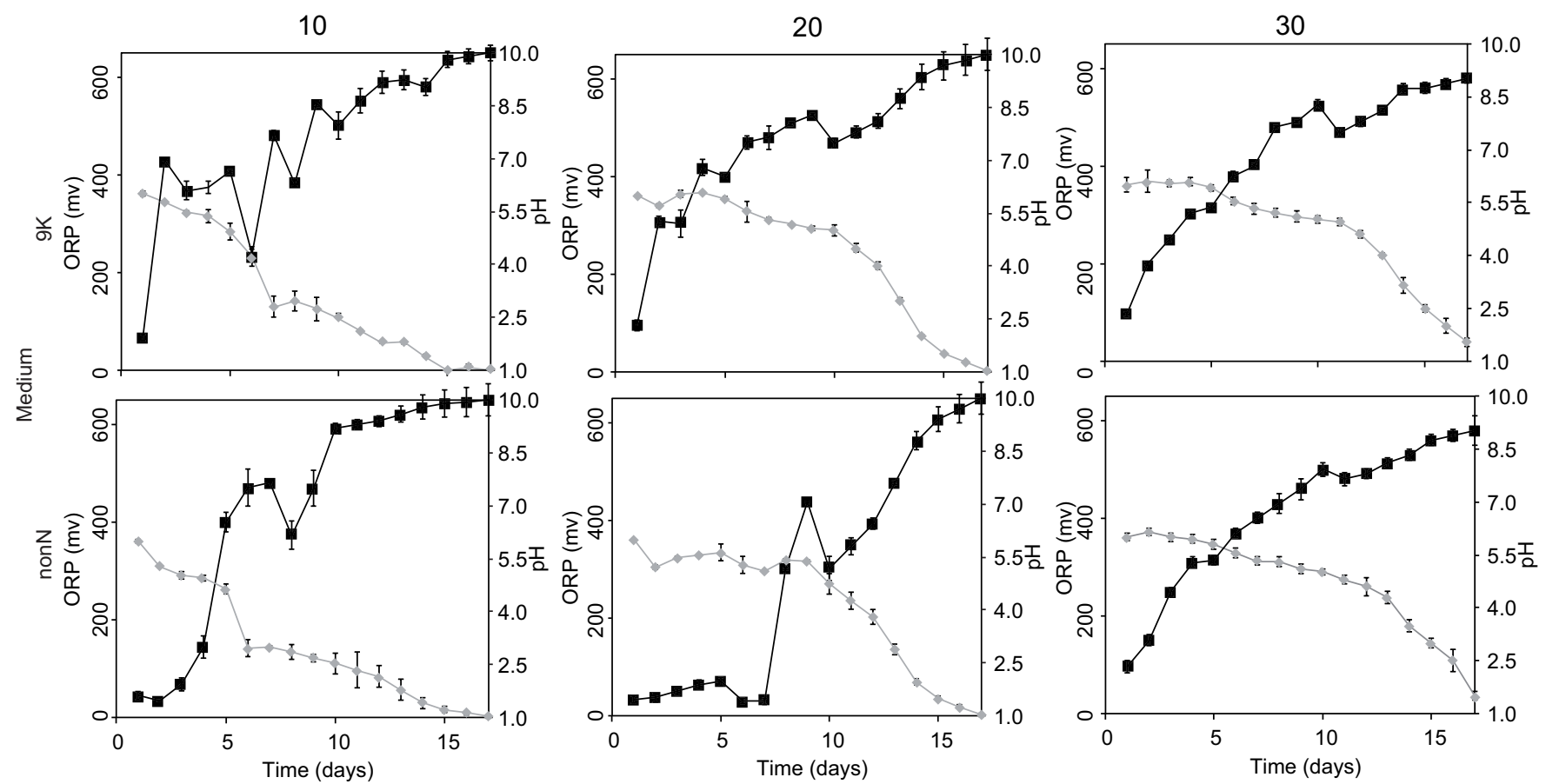

Fig. 5. Oxidation-reduction potential (ORP) and $\mathrm{pH}$ time course of biogenic ferric ion oxidized with nitrogen source (9K) and oxidized without nitrogen source (nonN) at three tailing concentrations and two biogenic ferric ion source. Oxide reduction potential: $\mathbf{\square} ; \mathrm{pH}$ : 
the first experiment were obtained. It is evident that the production and sustentation of leaching media are essential to achieve an effective process (Nguyen et al. 2015b).

The media $9 \mathrm{~K}$ and nonN showed similar $\mathrm{pH}$ and ORP. However, as tailings concentrations increased, removals of metals were significantly lower $(p>0.05)$ in experiments with nonN medium compared to $9 \mathrm{~K}$ medium.

High concentrations of tailings require more leaching agents since high abundance of mineral compounds can consume protons from the continuous biosynthesis of $\mathrm{H}_{2} \mathrm{SO}_{4}$ while reducing $\mathrm{Fe}^{3+}$ ion.

In general, removals of metals in continuous supplementation of biogenic $\mathrm{H}_{2} \mathrm{SO}_{4}$, synthesized in two types of culture medium $(9 \mathrm{~K}$ and nonN) at different tailings concentrations $(10,20$ and $30 \%, \mathrm{w} / \mathrm{v})$ were higher or similar than the first experimental set.

$\mathrm{Zn}$ removal obtained in our experiments did not show a significant difference $(\mathrm{p}>0.05)$ compared to the first experimental set. In the same way, treatments with a $9 \mathrm{~K}$ acid medium were similar compared to a nonN acid medium.

These results are in agreement with Nguyen et al. (2015b), who reported 90 and $30 \%$ of Mn and Zn solubilization, respectively, in a medium without nitrogen sources (experiments were carried out at $5 \%$ of sediment and inoculated with Acidithiobacillus ferrooxidans).

Continuous supplementation of fresh medium, rich in $\mathrm{Fe}^{3+}$ ions and $\mathrm{H}_{2} \mathrm{SO}_{4}$, resulted in an improved leaching of $\mathrm{Mn}, \mathrm{As}$, and $\mathrm{Pb}$.

\section{CONCLUSIONS}

In the first set of experiments, at low tailings concentration $(<20 \%)$ and low initial $\mathrm{pH}(2)$, the main effects over metals removals was the acid medium in combination with high redox. It is interesting to note that the the highest $\mathrm{Zn}$ removal was observed at an initial $\mathrm{pH}$ of 6.

The second set of experiments showed that a medium without nitrogen added can achieve similar metals removal $(\mathrm{Mn}$ and $\mathrm{Pb})$ in all conditions as compared to $9 \mathrm{~K}$ medium.

The use of a medium without nitrogen source opens an opportunity to increase benefit-cost ratio by removing metals from tailings that would otherwise remain neglected, thus demonstrating the feasibility of using extra-cellular culture supernatants to catalyze mining bioleaching at competitive rates and efficiencies.

\section{ACKNOWLEDGMENTS}

We acknowledge the financial support provided by the mining company First Majestic Silver Corp. The excellent comments and suggestions of anonymous reviewers are appreciated. Scholarships and support to the researcher from the National Council for Science and Technology (CONACyT), are also gratefully acknowledged.

\section{NOTATION}

ICP-OES Inductively coupled plasma optical emission spectrometry

nonN Nitrogen-free medium

ORP Oxidation-reduction potential

PCR Polymerase chain reaction

XRD X-ray diffraction

\section{REFERENCES}

Ahmadi A., Khezri M., Abdollahzadeh A.A. and Askari M. (2015). Bioleaching of copper, nickel and cobalt from the low grade sulfidic tailing of golgohar iron mine, Iran. Hydrometallurgy 154, 1-8.

DOI: 10.1016/j.hydromet.2015.03.006

Akcil A. and Gahan C.S. (2015). Application of industrial waste in biohydrometallurgy: A review on its use as neutralising agent and potential source for metal recovery, microbiology for minerals, metals, materials and the environment. In: Microbiology for minerals, metals, materials and the environment (Abhilash P., Pandey B.D. and Natarajan K.A., Eds.). CRC Press, Taylor Francis, Boca Raton, USA, pp. 185-208.

Akinci G. and Guven D.E. (2011). Bioleaching of heavy metals contaminated sediment by pure and mixed cultures of Acidithiobacillus spp. Desalination 268 (1-3), 221-226. DOI: 10.1016/j.desal.2010.10.032

Altschul S.F., Gish W., Miller W., Myers E.W. and Lipman D.J. (1990). Basic local alignment search tool. J. Mol. Biol. 215 (3), 403-410.

DOI: 10.1016/S0022-2836(05)80360-2

Askari-Zamani M.A., Hiroyoshi N., Tsunekawa M., Vaghar R. and Oliazadeh M. (2005). Bioleaching of sarcheshmeh molybdenite concentrate for extraction of rhenium. Hydrometallurgy 80 (1-2), 23-31.

DOI: 10.1016/j.hydromet.2005.06.016

Backman C.M. (2008). Global supply and demand of metals in the future. J. Toxicol. Environ. Health Part A 71 (18), 1244-1253.

DOI: $10.1080 / 15287390802209582$ 
Bafghi M.S., Zakeri A., Ghasemi Z. and Adeli M. (2008). Reductive dissolution of manganese ore in sulfuric acid in the presence of iron metal. Hydrometallurgy 90 (2-4), 207-212. DOI: 10.1016/j.hydromet.2007.07.003

Bellenberg S., Díaz M., Noël N., Sand W., Poetsch A., Guiliani N. and Vera M. (2014). Biofilm formation, communication and interactions of leaching bacteria during colonization of pyrite and sulfur surfaces. Res. Microbiol. 165 (9), 773-781.

DOI: $10.1016 /$ j.resmic.2014.08.006

Clevenger G.H. and Caron M.H. (1925). The treatment of manganese-silver ores. Bureau of Mines, Government Printing Office, Washington, USA, $110 \mathrm{pp}$.

Cohn C., Mueller S., Wimmer E., Leifer N., Greenbaum S., Strongin D. and Schoonen M. (2006). Pyrite-induced hydroxyl radical formation and its effect on nucleic acids. Geochem. Trans. 7 (3), 1-11.

DOI: $10.1186 / 1467-4866-7-3$

Corbett M.K. (2011). Leptospirillum: a study of the nitrogen fixing capabilities. Ph. D. Thesis. Faculty of Health Sciences, Curtin University of Technology, Curtin, Australia, 202 pp.

Davis D.G. and Jacobsen W.R. (1960). Determination of iron and iron-aluminum mixtures by titration with EDTA. Anal. Chem. 32 (2), 215-217.

DOI: $10.1021 / \mathrm{ac} 60158 \mathrm{a} 024$

Dodson J., Hunt A., Parker H., Yang Y. and Clark J. (2012). Elemental sustainability: Towards the total recovery of scarce metals. Chem. Eng. Process. 51, 69-78. DOI: 10.1016/j.cep.2011.09.008

Fonti V., Dell'Anno A. and Beolchini F. (2016). Does bioleaching represent a biotechnological strategy for remediation of contaminated sediments? Sci. Total Environ. 563-564, 302-319. DOI: 10.1016/j.scitotenv.2016.04.094

Gandhi S.M. and Sarkar B.C. (2016). Mineral deposits: Types and associations. In: Essentials of mineral exploration and evaluation (Saphiro A., Ed.). Elsevier, Amsterdam, Netherlands, pp. 23-52.

DOI: 10.1016/B978-0-12-805329-4.00009-0

Gericke M. and Pinches A. (1999). Bioleaching of copper sulphide concentrate using extreme thermophilic bacteria. Miner. Eng. 12 (8), 893-904.

DOI: $10.1016 / \mathrm{s} 0892-6875(99) 00076-\mathrm{x}$

Gericke M., Muller H.H., van Staden P.J. and Pinches A. (2008). Development of a tank bioleaching process for the treatment of complex Cu-polymetallic concentrates. Hydrometallurgy 94 (1-4), 23-28.

DOI: $10.1016 /$ j.hydromet.2008.05.018

Ghosh S. and Das A.P. (2017). Bioleaching of manganese from mining waste residues using Acinetobacter $s p$. Geology, Ecology, and Landscapes. 1 (2), 77-83.

DOI: $10.1080 / 24749508.2017 .1332847$
Graedel T. and Cao J. (2010). Metal spectra as indicators of development. P. Natl. Acad. Sci. Usa. 107 (49), 20905-20910.

DOI: 10.1073/pnas.1011019107

Ijadi Bajestani M., Mousavi S.M. and Shojaosadati S.A. (2014). Bioleaching of heavy metals from spent household batteries using Acidithiobacillus ferrooxidans: Statistical evaluation and optimization. Sep. Purif. Technol. 132, 309-316.

DOI: 10.1016/j.seppur.2014.05.023

Illumina (2007). Preparing samples for sequencing genomic DNA. Illumina, San Diego CA, USA, 20 pp.

Jiang H., Xie, F. and Dreisinger, D.B. (2015). Comparative study of auxiliary oxidants in cyanidation of silver sulfide. Hydrometallurgy 158, 149-156.

DOI: 10.1016/j.hydromet.2015.09.015

Jiang T., Yang Y., Huang Z., Zhang B. and Qiu G. (2004). Leaching kinetics of pyrolusite from manganese-silver ores in the presence of hydrogen peroxide. Hydrometallurgy 72 (1-2), 129-138.

DOI: $10.1016 / \mathrm{s} 0304-386 x(03) 00136-1$

Johnson D.B. (2014). Biomining-biotechnologies for extracting and recovering metals from ores and waste materials. Curr. Opin. Biotechnol. 30, 24-31.

DOI: 10.1016/j.copbio.2014.04.008

Keeling S.E., Palmer M.L., Caracatsanis F.C., Johnson J.A. and Watling H.R. (2005). Leaching of chalcopyrite and sphalerite using bacteria enriched from a spent chalcocite heap. Miner. Eng. 18 (13-14), 1289-1296. DOI: 10.1016/j.mineng.2005.05.015

Lavalle L., Giaveno A., Pogliani C. and Donati E. (2008). Bioleaching of a polymetallic sulphide mineral by native strains of Leptospirillum ferrooxidans from Patagonia, Argentina. Process Biochem. 43 (4), 445 450. DOI: $10.1016 /$ j.procbio.2007.10.019

Levicán G., Ugalde J.A., Ehrenfeld N., Maass A. and Parada P. (2008). Comparative genomic analysis of carbon and nitrogen assimilation mechanisms in three indigenous bioleaching bacteria: predictions and validations. BMC Genomics 9, 581-581.

DOI: $10.1186 / 1471-2164-9-581$

Li J., Zhong T.-K. and Wadsworth M. E. (1992). Application of mixed potential theory in hydrometallurgy. Hydrometallurgy 29 (1-3), 47-60. DOI: $10.1016 / 0304-386 \mathrm{X}(92) 90005-\mathrm{K}$

Li J. and Wadsworth M.E. (1993). Electrochemical study of silver dissolution in cyanide solutions. J. Electrochem. Soc. 140 (7), 1921-1927. DOI: 10.1149/1.2220740

Liu J.-S., Xie X.-H., Xiao S.-M., Wang X.-M., Zhao W.J. and Tian Z.-L. (2007). Isolation of Leptospirillum ferriphilum by single-layered solid medium. J. Cent. South Univ. T. 14 (4), 467-473. DOI: $10.1007 / \mathrm{s} 11771-007-0091-3$ 
Lombardi A.T. and Garcia Jr. O. (2002). Biological leaching of $\mathrm{Mn}, \mathrm{Al}, \mathrm{Zn}, \mathrm{Cu}$ and $\mathrm{Ti}$ in an anaerobic sewage sludge effectuated by Thiobacillus ferrooxidans and its effect on metal partitioning. Water Res. 36 (13), 3193-3202. DOI: 10.1016/S0043-1354(02)00008-8

Luo Y. and Millero F.J. (2003). Solubility of rhodochrosite $\left(\mathrm{MnCO}_{3}\right)$ in $\mathrm{NaCl}$ solutions. J. Solution Chem. 32 (5), 405-416. DOI: 10.1023/A:1024568711020

Macías F., Caraballo M.A. and Nieto J.M. (2012). Environmental assessment and management of metal-rich wastes generated in acid mine drainage passive remediation systems. J. Hazard. Mater. 229-230, 107-114. DOI: 10.1016/j.jhazmat.2012.05.080

Marchevsky N., Barroso Quiroga M.M., Giaveno A. and Donati E. (2017). Microbial oxidation of refractory gold sulfide concentrate by a native consortium. T. Nonferr. Metal. Soc. 27 (5), 1143-1149. DOI: $10.1016 / \mathrm{S} 1003-6326(17) 60133-\mathrm{X}$

McPhail D., Summerhayes E., Welch S. and Brugger J. (2003). The geochemistry and mobility of zinc in the regolith. In: Advances in regolith (Roach I.C., Ed.). Cooperative Research Centre for landscape Environments and Mineral Exploration, Millaa Millaa, Australia, pp. 287-291.

Mireles J. (2015). Management of the central metallurgy/ geochem laboratory. Personal communication, April 10.

Mousavi S.M., Yaghmaei S., Vossoughi M., Jafari A., Roostaazad R. and Turunen I. (2007). Bacterial leaching of low-grade $\mathrm{ZnS}$ concentrate using indigenous mesophilic and thermophilic strains. Hydrometallurgy 85 (1), 59-65. DOI: 10.1016/j.hydromet.2006.08.003

Nguyen V.K., Lee M.H., Park H.J. and Lee J.-U. (2015a). Bioleaching of arsenic and heavy metals from mine tailings by pure and mixed cultures of Acidithiobacillus spp. J. Ind. Eng. Chem. 21, 451-458.

DOI: $10.1016 /$ j.jiec.2014.03.004

Nguyen V.K., Tran T., Han H.-J., Lee S.-H. and Lee J.-U. (2015b). Possibility of bacterial leaching of antimony, chromium, copper, manganese, nickel, and zinc from contaminated sediment. J. Geochem. Explor. 156, 153161. DOI: 10.1016/j.gexplo.2015.05.012

Olyaei Y., Aghazadeh S., Gharabaghi M., Mamghaderi H. and Mansouri J. (2016). Gold, mercury, and silver extraction by chemical and physical separation methods. Rare Metal Mat. Eng. 45 (11), 2784-2789. DOI: $10.1016 / \mathrm{S} 1875-5372(17) 30040-1$

Parro V. and Moreno-Paz M. (2003). Gene function analysis in environmental isolates: The nif regulon of the strict iron oxidizing bacterium Leptospirillum ferrooxidans. P. Natl. Acad. Sci. Usa. 100 (13), 78837888. DOI: $10.1073 /$ pnas. 1230487100

Patiño F., Flores M.U., Reyes I. A., Islas H., Reyes M. and Juárez G. (2014). Kinetic modeling of the alkaline decomposition and cyanidation of Argentian plumbojarosite. J. Mex. Chem. Soc. 58 (1), 3-10.

Peng J.-H., Zhang R.-Y., Zhang Q., Zhang L.-M. and Zhou H.-B. (2008). Screening and characterization of Acidiphilium sp. PJH and its role in bioleaching. T. Nonferr. Metal. Soc. 18, 1443-1449.

DOI: 10.1016/S1003-6326(09)60023-6

Qiu X.-Y., Hu Z., Song B.-X., Li H.-W. and Zou J.-J. (2014). A novel process for silver recovery from a refractory $\mathrm{Au}-\mathrm{Ag}$ ore in cyanidation by pretreatment with sulfating leaching using pyrite as reductant. Hydrometallurgy 144-145, 34-38.

DOI: $10.1016 /$ j.hydromet.2014.01.016

Ram R.J., VerBerkmoes N.C., Thelen M.P., Tyson G.W., Baker B.J., Blake R.C., Shah M., Hettich R.L. and Banfield J.F. (2005). Community proteomics of a natural microbial biofilm. Science 308 (5730), 1915-1920. DOI: 10.1126/science. 1109070

Rohwerder T., Gehrke T., Kinzler K. and Sand W. (2003). Bioleaching review part A. Appl. Microbiol. Biotechnol. 63 (3), 239-248. DOI: 10.1007/s00253-003-1448-7

Sato Y., Hosokawa K., Fujimura R., Nishizawa T., Kamijo T. and Ohta H. (2009). Nitrogenase activity (acetylene reduction) of an iron-oxidizing Leptospirillum strain cultured as a pioneer microbe from a recent volcanic deposit on Miyake-Jima, Japan. Microbes Environ. 24 (4), 291-296. DOI: 10.1264/jsme2.ME09139

Steger H.F. (1976). Chemical phase-analysis of ores and rocks: A review of methods. Talanta 23 (2), 81-87. DOI: 10.1016/0039-9140(76)80028-8

Sun X., Guan Y.C. and Han K.N. (1996). Electrochemical behavior of the dissolution of gold-silver alloys in cyanide solutions. Metall. Mater. Trans. B 27 (3), 355-361. DOI: 10.1007/BF02914898

Takeno N. (2005). Atlas of Eh-pH diagrams. Intercomparison of thermodynamic databases. Geological Survey of Japan Open File Report No. 419. National Institute of Advanced Industrial Science and Technology, Research Center for Deep Geological Environments, Osaka, Japan. 285 pp.

Tian Q.-H., Jiao C.-Y. and Guo X.-Y. (2012). Extraction of valuable metals from manganese-silver ore. Hydrometallurgy 119-120, 8-15.

DOI: 10.1016/j.hydromet.2012.03.005

Turek P., Bajda T. and Manecki M. (2015). Dissolution of mimetite $\mathrm{Pb} 5\left(\mathrm{AsO}_{4}\right) 3 \mathrm{Cl}$ in malic acid solutions. Mineralogia 45 (1-2), 3-12. DOI: 10.2478/mipo-2014-0001

Tyson G.W., Chapman J., Hugenholtz P., Allen E.E., Ram R.J., Richardson P.M., Solovyev V.V., Rubin E.M., Rokhsar D.S. and Banfield J.F. (2004). Community structure and metabolism through reconstruction of microbial genomes from the environment. Nature 428, 37-43. DOI: $10.1038 /$ nature 02340 
Tyson G.W., Lo I., Baker B.J., Allen E.E., Hugenholtz P. and Banfield J.F. (2005). Genome-directed isolation of the key nitrogen fixer Leptospirillum ferrodiazotrophum sp. nov. from an acidophilic microbial community. Appl. Environ. Microbiol. 71 (10), 6319-6324. DOI: 10.1128/aem.71.10.6319-6324.2005

UNEP (2009). Critical metals for future sustainable technologies and their recycling potential. Sustainable innovation and technology transfer industrial sector studies. United Nations Environment Programme, Paris, France, 81 pp.

Viñals J. and Núñez C. (1988). Dissolution kinetics of Argentian plumbojarosite from old tailings of sulfatizing roasting pyrites by $\mathrm{Hcl}-\mathrm{CaCl}_{2}$ leaching. Metall. Trans. B 19, 365-373.

DOI: $10.1007 / \mathrm{BF} 02657734$

Wang H. and Pan X. (2014). Role of extracellular polymeric substances (EPS) from Pseudomonas putida strain MnB1 in dissolution of natural rhodochrosite. Biogeosciences 11 (5), 7273-7290.

DOI: $10.5194 /$ bgd-11-7273-2014

Watling H. (2015). Review of biohydrometallurgical metals extraction from polymetallic mineral resources. Minerals 5 (1), 1-60. DOI: 10.3390/min5010001

Welcher F.J. (1963). A text-book of quantitative inorganic analysis including elementary instrumental analysis (Vogel, Arthur I.). J. Chem. Educ. 40, A68. DOI: 10.1021/ed040pA68
Yan-Fei Z., An-An P., Yu Y., Jian-She L. and Guan-Zhou Q. (2013). Isolation, characterization of Acidiphilium $s p$. DX 1-1 and ore bioleaching by this acidophilic mixotrophic organism. T. Nonferr. Metal. Soc. 23 (6), 1774-82. DOI: 10.1016/s1003-6326(13)62660-6

Yang H., Gao K., Feng S., Zhang L. and Wang W. (2015). Isolation of sulfide remover strain Thermithiobacillus tepidarius JNU-2, and scale-up bioreaction for sulfur regeneration. Ann. Microbiol. 65 (1), 553-563.

DOI: $10.1007 / \mathrm{s} 13213-014-0891-2$

Yu R.-L., Tan J.-X., Yang P., Sun J., Ouyang X.-J. and Dai Y.-J. (2008). EPS-contact-leaching mechanism of chalcopyrite concentrates by $A$. ferrooxidans. T. Nonferr. Metal. Soc. 18 (6), 1427-1432. zDOI: 10.1016/S1003-6326(09)60020-0

Yu R.-L., Zhong D.-L., Miao L., Wu F.-D., Qiu G.-Z. and Gu G.-H. (2011). Relationship and effect of redox potential, jarosites and extracellular polymeric substances in bioleaching chalcopyrite by Acidithiobacillus ferrooxidans. T. Nonferr. Metal. Soc. 21 (7), 1634-1640. DOI: 10.1016/S1003-6326(11)60907-2

Zhang R.-Y., Xia J.-L., Peng J.-H., Zhang Q., Zhang C.-G., Nie Z.-Y. and Qiu G.-Z. (2010). A new strain Leptospirillum ferriphilum YTW315 for bioleaching of metal sulfides ores. T. Nonferr. Metal. Soc. 20 (1), 135-141. DOI: 10.1016/s1003-6326(09)60110-2 